\title{
Aguas Broncas: The Regional Political Ecology of Water Conflict in the Mexico-U.S. Borderlands
}

\author{
Casey Walsh ${ }^{1}$, Universidad Iberoamericana
}

\begin{abstract}
Along the US-Mexico border, every summer is a long, hot, summer. The border crosses what was referred to in the nineteenth century as the "Great American Desert" (M. Reisner 1993), an expanse of arid and semi-arid lands where even the mountainous areas don't receive much rainfall. The coastal zones on both ends of the border are also quite hot and dry, save for the deluge caused by an occasional tropical storm or hurricane. The torrential runoff from these storms routinely overflows the banks of the rivers in the borderlands, flooding lowlying areas before washing up behind the hundreds of dams that dot the landscape. Even now, after a century of building irrigation and flood control works, these storms still cause loss of life and many millions of pesos or dollars of damages. Nevertheless, for much of the borderlands, these occasional weather systems are the only way to refill the reservoirs upon which the region has come to depend, and are welcomed despite the problems they cause.

While every summer is a hot one in the borderlands, in the summer of 2002 things heated up even more than usual. After nine years of less-than-average rainfall in the Rio Bravo (known as the Rio Grande in the United States) basin, water levels in the reservoirs that serve the agricultural and urban zones from New Mexico and Chihuahua to Gulf of Mexico had reached extraordinarily low levels. Water officials of both federal governments as well as state governments rationed and denied water of the Rio Bravo to agricultural users, in order to reserve water for urban and domestic uses. Between 1995 and 1999 drought had cut water deliveries by $50 \%$ to farmers in parts of the irrigated agricultural zone along the banks of the Rio Bravo in Northern Tamaulipas and South Texas, one of the most productive agricultural regions in north America. And, in 2000 and 2001, water was cut off altogether for many farmers in northern Tamaulipas. ${ }^{2}$ As it had during the previous decade, the Mexican government postponed the delivery of water from its tributaries to the international dams in the river's Lower Valley, deliveries mandated by the 1944 Water Treaty between Mexico and the US. ${ }^{3}$

In 2002 damage to the agriculture of the Lower Rio Bravo caused farmers on both sides of the border to step up pressure on their respective governments for a resolution of the water crisis. Their actions were seen and heard by news agencies and political representatives from Austin, Texas, to Ciudad Victoria, Tamaulipas and Chihuahua city, Chihuahua, and from Mexico City to Washington D.C. Newsweek, the New York Times and the Washington Post all covered the story of water shortages and treaty conflicts in the borderlands, as did National Public Radio and Mexico's major weekly newsmagazine Proceso. In general the conflict was described by the media as a "water war" that pitted the United States against Mexico.

In May of that year, farmers from the Texas side of the Lower Rio Grande Valley blockaded the key international bridge between Pharr and Reynosa with their tractors, while their representatives in the state and federal Congresses demanded that the governor and the President apply pressure on the Mexican federal government to release water from reservoirs upstream. ${ }^{4}$ Rick Perry, governing Texas in an election year, thundered on publicly about the "water war," and threatened a boycott of Mexican products and other sanctions if the farmers didn't get water from Mexico. Perry accused the Mexican government of evading compliance with the international water treaty that governs the waters of the Bravo, Colorado and Tijuana Rivers. There was plenty
\end{abstract}

1. The author would like to thank the Secretaria de Medioambiente y Recursos Naturales (SEMARNAT), Mexico, and the Universidad Iberoamericana for supporting this research. Many of the references cited were found at the website of the Rio Grande/Rio Bravo Basin Coalition: www.rioweb.org.

2. Between 1995 and 1999, water deliveries to the Valle Bajo Rio Bravo Irrigation District (\#025) around the town of Matamoros, Tamaulipas, Mexico, fell from 860 million cubic meters (Mm3) to $400 \mathrm{Mm} 3$. La Jornada (Oct. 1, 2001).

3. Farmers in the Rio Grande Valley of South Texas noticed shortfalls in water deliveries since about 1993. Diario de Juarez (March 19, 2002).

4. Texas senator Kay Bailey Hutchinson pressured the White House for water deliveries from Mexico, while Texas farmers planned seizures of border bridges. El Reforma (May 3, 2002). 


\section{Casey Walsh}

of water, argued Perry, behind dams on the Rio Conchos, in the state of Chihuahua. ${ }^{5}$ Texas Agricultural Commissioner Susan Combs produced satellite images that showed, she said, that farmers in Chihuahua were irrigating at the same time that farmers in South Texas watched their crops wither in the fields. ${ }^{6}$ Mexico was failing to comply with the 1944 Water Treaty by not releasing that water, Perry and the Texas farmers argued, and they called upon fellow Texan George W. Bush to apply pressure on Mexico to release water. ${ }^{7}$ US ambassador to Mexico, Jeffrey Davidow, reproduced the argument about Treaty incompliance in the Mexico City press, generating sharp rebuttals from the Mexican government. ${ }^{8}$ Attracted by the stink of international rancor, policy analysis institutions such as Washington's Center for Strategic International Studies and Public Strategies Inc. in Austin, Texas warned of a new era of tensions between the countries.

In this paper I present a "regional, particularist" (J. Heyman 1994) understanding of the political conflict over water in the Rio Bravo basin. I interrogate the national postures taken in the present conjuncture and identify a longstanding regional, binational political consciousness in the Rio Bravo/Grande delta based in the recognition of economic and social interdependence and a common ecological position in relation to the rest of the river basin. These national and binational/regional political tendencies are tightly interwoven, and, given the predominance of federal government power in the border region, regional actors are often the ones to launch nationalist political projects in order to achieve their goals. Considering the current efforts to decentralize water governance and achieve a sustainable use of the resource, it is this binational and regional dynamic that must be understood and encouraged.

My argument has two parts. First, my description of the present conflict attends to its historical and regional dynamics. The conflict, I argue, is a symptom of the crisis of the irrigated agricultural development model that was implemented in the region at the beginning of the twentieth century, and has expanded continuously since. This development model is currently being displaced by one centered on urbanization and industrial and service sector growth. I argue that while this long ecological and economic history of irrigated agricultural development is certainly characterized by competition and antagonism between the United States and Mexico, significant alliances have been formed across the international border, especially in regions such as the binational agricultural zone that occupies the delta of the Rio Bravo; that is, the Lower Rio Grande/Bravo Valley of South Texas and Northern Tamaulipas. The farmers on both sides of the Lower Rio Grande/Bravo share a common geographical and ecological position in relation to regions higher up in the river basin, which provides a basis for congruent and sometimes collaborative political projects to secure water.

The second part of my paper concentrates on the conflicts over water that has attracted so much attention over the last few years: what has been labeled the "water war." I discuss recent legal and political skirmishes between regional actors and the two federal governments, focusing especially on the binational Lower Valley and on dynamics within Mexico, where recent notable shifts in the relation of political forces have contributed to and resulted from the water conflict. These changes include a fragmentation of the political system between three main parties, the emergence of a discourse of legality and the "rule of law," and efforts to decentralize or federalize politics, and water management politics in particular. I conclude the paper by pointing to some of the elements of this conflict that could form a basis for a more sustainable management and use of water in the borderlands. In particular, I am interested in the way regional actors in northern Tamaulipas have made use of Mexico's legal system, and how their political struggle to secure water has also been a process of self-education in the legal and technical details of water management. I am also encouraged by the ability of actors to work cooperatively across the Mexico-US border. These elements offer hope for a more democratic, participatory and

5. $\quad$ Proceso (May 19, 2002) p. 9.

6. Combs based her assessment of the water resources in Chihuahua on a report produced by the Center for Space Resources in Austin, Texas. "Bush Won't Discuss Water Debt with Fox" McAllen Monitor (March 14, 2002). El Bravo de Matamoros (May 16, 2002).

7. McAllen Monitor (March 22, 2002); El Universal (March 22, 2002).

8. El Universal (April 15, 2002); El Reforma (April 16,2002)

9. See "The June 2002 Mexico Report" produced by Public Strategies, Inc. of Austin Texas. 
Aguas Broncas

sustainable management of water resources in the borderlands.

\section{DEVELOPMENT IN THE BORDERLANDS}

When US settlers and colonists began occupying dry lands west of the 100th meridian in the late nineteenth century, they encountered small-scale irrigation systems that supported small populations along the banks of rivers such as the Pecos, Nueces, Grande and Colorado. Many of the irrigated agricultural systems were originally built before the arrival of the Spaniards. In the 17th century, with the opening of silver mines by the Spanish crown in what is now Northern Mexico and the Southwest US, groups of indigenous people from the Tlaxcala region of central Mexico brought their Mesoamerican irrigation systems to the arid lands (T. Martínez Saldaña 1999). Some of these irrigation systems are still in operation, but many have been destroyed or have been superceded by larger works. By the beginning of the twentieth century, technological advances allowed the construction of more extensive irrigation systems, and paved the way for a flourishing capitalist agricultural economy in the arid borderlands.

Commercial agricultural development in the borderlands depended on three principal ingredients. First, cheap, scarcely populated land was converted to agricultural land by providing water. Pumps, dams and canals allowed this transformation of ranchland or wilderness into farmland. Second, in order for the new agricultural zones to function in this scarcely populated region, labor was needed. One possible solution was seen in the small, self-sufficient colonist farmer. But more often than not large industrial farms were set up that created a huge demand for imported seasonal labor. With the construction of the rail system in the region during the last two decades of the nineteenth century, permanent migrant labor circuits were established that brought workers from central Mexico north to the agricultural zones of the borderlands. Finally, these irrigation zones produced particular commodities that commanded high prices in distant markets. While new refrigerated rail cars gave rise to a boom in the production of fresh fruits and vegetables, the crop of choice for much of the borderlands irrigated agricultural zones was cotton (C. McWilliams 1942; W. Meyers 1994; D. Montejano 1987; M. Plana 1991; C. Walsh 2001; D. Weber 1994). Cotton was particularly well-suited to the extreme temperatures of the borderlands and the kind of periodic soakings provided by the new large-scale irrigation systems (P. Porter 1995). And, because it was not perishable, it was the perfect crop for agricultural zones located far from industrial markets in the northeast US and Europe (V. Bernal 1991; A. Isaacman.1996; R. Roberts 1996; V. Peloso 1999).

The principal rivers of the southwest, the Colorado and the Bravo/Grande, pass through many states in both the US and Mexico on their way to the ocean, and the efforts to control their waters for use in agricultural development made necessary a legal framework that established the water rights of users. In the conflicts that arose between users and their political representatives two different legal concepts were deployed to claim water rights: that of priority in time; and that of priority in space. Priority in time meant that those who arrived first established claims to water that could not be transcended later. Priority in space meant that whoever got the water upstream had the right to the water, regardless of the uses already established for that water downstream. Struggles to control the scarce water resources of the Rio Bravo arose as early as the 1870s, when the expansion of irrigated agriculture in the states of Colorado and New Mexico combined with a drought to threatened the water supply of Mexican agricultural zones and towns in the Juarez Valley around El Paso (N. Hundley Jr. 1966, Ch. 2). Later, around the turn of the century, the construction of the Elephant Butte dam threatened to use all the water of the Rio Grande before it got to Mexico. Governments and water users in the United States backed their monopolization of the resource with the concept of priority in space. Mexico responded by claiming the water that had previously been used by farmers in the Juarez Valley: priority in time. At the same time, in the Mexican side of the delta region of the Colorado, various US development companies including a group of Los Angeles capitalists headed by Harry Chandler were eagerly buying up water rights awarded by the Mexican government in the 1850 s to Mexican colonists (J. Greenberg 1998; D. Kerig 2001; E. Ward 2003; D. Worster 1985). Here the concept of prior in time was deployed to defend water rights. Put simply, each water user and government used each legal concept to claim water rights when it was convenient to do so. These early struggles over the water of the international rivers, when added to more than a half century of US adventurism and intervention, generated the belief among Mexican hydraulic engineers and state actors that the politics of water was, to use the phrase of Von Clausewitz, "war by other means." 
Between 1910 and 1920, the US government was busy building dams and colonizing its western expanses. As more and more people sought to use the scant water resources of the Southwest, the federal government pressured the state governments to come to an agreement over the partition of the waters of the Colorado river. At the same time, it sought to reach a legal accord with Mexico over the waters of the international rivers. Meanwhile, Mexico plunged into civil water. The Mexican revolution plays a key role in this story of irrigated agricultural development in the borderlands for a number of reasons. First, because of the hostilities, irrigated agricultural development in Mexico stagnated, while farmers in the US made use of ever-greater quantities of water. Second, it was the mass of underpaid, underemployed migrant workers generated by borderlands agricultural development that formed a good part of the rank and file of the northern armies (W. Meyers 1994; W. Meyers 1998). The generals of the northern armies knew this well, and when they won the revolution and set about building a new state, they made the pacification of these soldier-workers a priority. Furthermore, the role of the US in supporting different revolutionary and government factions fomented nationalism among Mexico's new leaders, who saw their northern neighbor as a constant threat to the sovereignty of their country.

In Mexico, irrigation was seen as the solution to all these problems. It was thought that with the creation of new irrigated agricultural zones, soldier-workers could be demobilized, settled and pacified (Walsh 2004). These new colonists would also establish a patriotic presence on a tenuously held border, counteracting the influence of the United States in the region. Furthermore, by building hydraulic infrastructure and using the water of the international rivers, Mexico would establish water claims to improve its position in the negotiations for the binational water Treaty. Lastly, these irrigation zones would form the heart of a national development strategy based on the export of commercial crops, especially cotton (L. Aboites 1987; A. Warman 2001). In the last years of the first world war and into the 1920s cotton commanded exceptionally high prices on the world market, and irrigation officials in Mexico viewed the commodity as a way to pay for expensive hydraulic works and the costs of settling colonists in the irrigation zones (Comisión Nacional de Irrigación 1930).

In 1926 Mexican president Plutarco Elias Calles moved ahead with a national irrigation program by promoting two related laws on irrigation and colonization (Aboites 1987). These laws created the National Irrigation Commission (the CNI), which took as its first priority the creation of irrigation systems on the tributaries of the Rio Bravo: the Conchos, Salado and San Juan rivers. Efficient urban and domestic planning would facilitate the movement of commodities, and would create social spaces for the new citizens of the irrigation systems. To ensure the success of these irrigated agricultural development projects, colonists were sought among those Mexicans who had lived and worked in the United States. Repatriated Mexican migrants would, it was thought, bring to these development projects a more elevated standard of living, modern work discipline and progressive productive culture learned in the United States (F. Balderrama and R. Rodríguez 1995; M. Gamio 1931; M. Gamio 1987(1935); Comisión Nacional de Irrigación 1928). It was also thought that these repatriados would make exceptionally patriotic citizens, for they possessed a heightened sense of national pride. The patriotism and national identity of these colonists would help Mexico defend its northern border against the cultural dimensions of US imperialism.

The building of irrigation zones in Mexico's northern border had clearly articulated strategic international goals. Mexico's position was that any water treaty it signed with the US had to include both the Colorado and the Bravo rivers, and that it would not strike a bargain unless it was a good one. In the Mexican half of the Colorado river delta, no one could safely invest in agriculture until flood control works were built to protect the area from flooding, and a legal right to a share of the Colorado's water had been secured. While the American landowners in the Mexican side of the delta and their Mexican, Chinese and Japanese tenants generally did not suffer from water shortages in these early years of the twentieth century, in 1919 and 1920 Mexico's access to the water of the Colorado was threatened by plans to build a canal entirely in US territory: an "All-american Canal" that would divert the river and not deliver water to Mexico (M. Anguiano Tellez 1995; D. Kerig 2001; E. Ward 2003).

In order to pressure the US government into legally recognizing the primordial rights of Mexico to a large share of the Colorado River, the Mexican government threatened to take the water away from irrigated agricultural zones on the Texas side of the Lower Rio Bravo/Grande. Where the United States government's "All-American Canal" planned to divert the water of the Colorado before it reached Mexico, Mexico's new irrigated development zones were designed to use the water of the Rio Bravo before it reached Texas. Much as it is today, the Lower Rio 
Grande Valley of Texas was completely dependent on a steady supply of water reaching the mouth of the Rio Grande, and, at that time, about $90 \%$ of the irrigated lands on the Rio Bravo/ Grande were in the Lower Rio Grande Valley of Texas. The existing boundary treaties between the two countries prohibited anyone from building anything in the stretch of the river shared by the two countries that would impede its navigability or change its course, which meant that no dams could be built on the Rio Grande to safeguard a supply of water for the Valley. As Mexico built its new irrigation systems on the tributaries of the Rio Bravo during the late 1920s and 1930s, the farmers of the Lower Rio Grande Valley became increasingly worried about their access to the water that came down to them from those tributaries. They pressured the US federal government to negotiate a water treaty with Mexico that would assure them access to the resource, but struggles among the Colorado river states impeded progress.

During the administration of President Lázaro Cárdenas, the Mexican government increased the pressure. In an effort to control the disastrous floods that slammed into the Mexican side of the Rio Grande delta in the early 1930s, in 1936 Mexico's Secretary of Communications and Public Works began work on a system of levees and canals that would both protect the agricultural lands around Matamoros, and provide irrigation to greatly expand that agricultural zone. The key ingredients of this flood control system were a series of floodgates along the river, with canals that would conduct floodwaters by gravity to a reservoir built in an ancient lakebed to the south of the river. Prohibited by existing treaties from building a dam on the river to control these frequent floods, Mexico's plan sought to reduce flooding and, at the same time, store water for later use. The grazing lands surrounding Matamoros, held in common among the descendants of the original colonists of the region, were divided by the government and distributed among former sharecroppers and recently repatriated migrants, who cleared the land and prepared it for agriculture. The new agricultural zone was to be dedicated entirely to cotton, by order of the Federal government. ${ }^{10}$ The farmers of the Texas side of the Valley, fearful of losing the water on which their livelihoods depended, accused Mexico of diverting the flow of the Rio Bravo, and sent angry demands to their congressional representatives. ${ }^{11}$ While the complaints made to Washington were aimed at having the Mexican government halt construction of the works, the more important goal of regional representatives from South Texas was to pressure their own Federal government into signing an international water treaty that would divide the waters among all the different regions of the river basin, both in Mexico and the United States, and allow the construction of an international dam on the Rio Bravo/Grande to supply the delta. "Only the national governments can do these things," the secretary of the Valley Water Conservation Association told a local reporter, "but pressing for their accomplishment is our responsibility". ${ }^{12}$

The long struggle between the federal governments of México and the US to "divide the waters" of the international rivers has been described at length by historians (N. Hundley Jr. 1966; E. Enríquez Coyro 1976). What is generally lost in these accounts of diplomatic history however, are the complex regional dynamics that contributed to the struggle; dynamics that often showed as much cooperation as conflict across the border. For example, when the representatives of the Texas Valley began pressuring their federal government to take action, the director of the Mexican flood control and irrigation project, Eduardo Chávez, worked to reassure the Texans that the works would benefit both sides of the river. In a presentation before engineers, farmers and local leaders in Brownsville in May of 1940, he argued that there was not enough room in the river channel for the seasonal floodwaters, that the river had always overflowed its banks, and that building levees would simply cause uncontrolled flooding on the side of the river with the shorter levees. ${ }^{13} \mathrm{~A}$ permanent solution, he argued, was to divert the floodwaters into dry lakebeds where it could be stored for irrigation, or, in the case of extreme flooding, to the Gulf of Mexico. All that was

10. Archivo General de la Nación, México (AGN); Fondo Cárdenas; 508.1/490; "Decreto". AGN; Cárdenas; 508.1/490 “Acuerdo" (4-24-39).

11. "Valley's Water Supply at Crisis" Brownsville Herald (5-3-36); "New Appeals for Quick Rio Action Made" Brownsville Herald (5-27-36); "Mexico Continues Retamal Project; F.D. Misinformed" Brownsville Herald (6-21-36).

12. "Resume of Water Projects Reveals Need for Treaty" Brownsville Herald (6-25-36).

13. "US, Mexico Engineers Plan Informal Parley on Water Problems" Brownsville Herald (5-21-40) 


\section{Casey Walsh}

needed was for the two sides of the river delta to understand their shared ecology, and cooperate in managing it. "The one thing which will insure the continued prosperity and happiness of our entire Valley," Chávez told the audience, "will be the keen and complete realization that our concerns in these water problems are mutual". ${ }^{14}$

Water administrators from the irrigation districts of South Texas who attended Chavez' presentation echoed the Mexican engineer's call for cooperation between the two sides of the delta region. "We can settle our problems in a democratic, peaceful manner," said Frank Robertson, manager of the San Benito water district,

if the people most vitally interested can get their feet under the same table and talk turkey without any diplomatic strings attached. Then we can tell our governments what is needed, and we can get this thing done. There is plenty of water, more than enough for all of us... ${ }^{15}$

Nevertheless, leaders from South Texas recognized that, once the irrigation system and agricultural zone was built, nothing stopped farmers in Matamoros from pumping water from the Rio Grande to irrigate their fields, as Texans had been doing for decades. Complementing the cooperative disposition of regional leaders, the threat to the water supply of one of the richest and most productive agricultural zones in the United States motivated plans to build a massive gravity irrigation scheme on the Texas side of the river - another "All-American Canal" - to compete with the Mexican project and increase pressure on the federal governments to reach a new treaty agreement. ${ }^{16}$

The treaty between Mexico and the United States that today governs the distribution of the waters of the international rivers was signed in 1944 after more than twenty years of false starts and political skirmishes between the two countries and many states that share the resource. It is important to understand some basic elements of the 1944 Treaty, in order to understand recent conflicts over the water that is governed by it. Recognizing previously established water rights, the Treaty stipulated that some 1,850 million cubic meters of water be delivered annually by the United States to the region of Mexicali in Mexico. The United States was awarded the right to all of the water from the Pecos and Devil rivers, the Goodenough springs, and the flows of the Alamito, Terlingua, San Felipe and Pinto arroyos. The US also received the right to one third of the flows that arrive to the Rio Bravo from Mexico by way of the Conchos, San Diego, San Rodriguez, Escondido and Salado Rivers as well as the Arroyo de las Vacas. Mexico was made responsible for delivering a yearly average of 431 million cubic meters of water to the Texas side of the Rio Grande Valley from these rivers, calculated over cycles of 5 years. The Treaty recognizes that the meteorological conditions of the borderlands may make minimum water deliveries from Mexico to the Rio Grande impossible in any given year or two, but assumes that over cycles of five years these shortfalls will be compensated. According to the document, if conditions of exceptional drought are present, and Mexico fails to deliver the stipulated amount of water by the end of the five-year cycle, that amount, now considered a "debt", is added to the water delivery requirements of the following five-year cycle. Mexico was given the right to the remaining two-thirds of the flows of these same rivers, and it was decided that both countries would split equally whatever water appears in the Rio Grande/Bravo from sources that are not mentioned in the treaty. There are many more details in the Treaty, and some 308 operational minutes have been written and put into effect by the binational organism that manages the international rivers: the International Boundary and Water Commision (IBWC), called the Comision Internacional de Limites y Aguas in Mexico (CILA). Each national government is responsible for collecting and sharing data and managing the infrastructure in its own country.

The 1944 Water Treaty helped solidify the agricultural development model in the borderlands. Apart from securing and regulating existing water sources for regional agricultural

14. Ibid.

15. Ibid.

16. "Master Water District Gains RFC's Favorable Attitude" Brownsville Herald (5-31-36); "Valley Gravity Irrigation Plan Given Approval by Engineers" Brownsville Herald (2-11-40);

"Big River Project Would Give Valley Steady Water Supply” Brownsville Herald (3-12-40). 
zones, the Treaty established the legal bases for the construction of the two big international dams on the Rio Bravo/Rio Grande, the Falcon and the Amistad. These dams made it possible to store water in the course of the Rio Bravo/Rio Grande, for use in agriculture in the Lower Valley. About 40 thousand hectareas were irrigated in the Matamoros region in 1944 . With the international dams, by the mid-1950s that area had expanded to about 200,000 hectareas. Mexicali also grew after 1944. Most of these borderlands irrigation zones produced cotton, which commanded high post-war prices due to the fact that, because the US was by far the world's largest cotton grower, the domestic prices floors established by the US Commodity Credit Corporation boosted prices for the fiber in the world market. With water and markets assured, cotton agriculture in northern Mexico boomed, generating foreign currency income through exports, and creating along with it processing industries such as cotton gins and cottonseed oil presses. Plentiful cotton fiber also supported a national textile industry. Taken together, the activities related to borderlands agricultural development formed a great part of the dramatic postwar economic growth known as the "Mexican economic miracle", or "milagro mexicano" (F. Carmona et. al. 1996).

After 1944, the Lower Rio Bravo/Grande Valley became increasingly integrated as a binational region. Ecologically, both national halves of the region continued to be totally dependent on a single water source for their existence. Economically, workers, capital, technology, commodities and value flowed from one side to the other in a relation of unequal interdependency. Socially, inhabitants of the region sought the benefits offered by each side of the border, forging binational networks. In a paradox that should not surprise us, many of these binational, regional phenomena were established or promoted by the Mexican national government in its effort to establish sovereignty on its remote northern border by settling migrants and establishing irrigation zones. This dialectic between national state formation and regional binational social formation is a structural feature of the borderlands, and, as we shall see, is clearly present in current water conflicts.

There were other dialectical processes at work during this period as well. Even as the irrigated agricultural development model was consolidating in northern Mexico, it sowed the seeds of its own demise. First, monocrop production created enormous pest problems and impoverished the soil, while irrigation caused salinization. At the same time, the project of the US government to buy surplus cotton from its farmers in order to boost prices resulted in the accumulation of huge stocks of fiber. In 1957 the US government began to dump these huge cotton surpluses onto the world market, sending prices down and making it impossible for many farmers to make money from cotton growing in northern Mexico. Thus the very policies that supported Mexican cotton agriculture, soon undermined it. While agriculture in northern Mexico adapted to the changing conditions by switching from cotton to staple grains such as corn and sorghum (B. DeWalt 1985; C. Hewitt de Alcantara 1976), the whole agricultural development model was slowly being displaced by industry and urbanization. The industries created by cotton processing attracted workers to the border cities, and these urban centers grew greatly in the years after 1944 . When cotton crashed in places like Matamoros in the 1960s, local elites and the federal government stepped in with a program to spur industry; the Border Industrialization Program. This program laid the basis for the emergence of the maquiladora industry, which more than any other factor has led to explosive urban growth in the borderlands. Between 1944 and 2001, the population in the Mexican borderlands has expanded tenfold, from one million to eleven million. These demographic trends are also seen on the Texas side of the border in places like the Lower Rio Grande Valley, or El Paso, where once rural and agricultural-based economies are quickly changing to industrial and service-based economies (J. Peach and J. Williams 2000). At present, wages from maquiladoras and other activities are more important to the domestic economy of most rural households in the Matamoros region than income from agriculture. Many of these maquiladoras are now located in small agricultural towns, or even in trailers parked in ejidos.

Although something like $80 \%$ of the water of the Rio Grande/Bravo is still dedicated to agriculture, the pressure placed on the resource by urban, industrial users has increased greatly over the last twenty years (Kelley et al 2001; I. Coronado 1999). The case of the city of Monterrey makes this point evident. In the 1980s Monterrey experienced water rationing as its population growth greatly outstripped its water resources (Bennet 1996). In response to the social and political crisis caused by water shortages in that city, in the early 1990s the federal government built a dam on the upper San Juan river. The Cuchillo dam captured and diverted water from a river that had, since the early 1940s, been almost completely devoted to supporting agriculture in 


\section{Casey Walsh}

northern Tamaulipas. The deep conflict that resulted between regions, between state governments and between urban and rural users is evidence of how the crisis of irrigated agriculture is directly associated with industrial and urban development. This crisis is also clearly manifested in those events mentioned at the beginning of the paper, described by many as the "water war." Having provided some idea of the historical, regional character of development in the borderlands, I will now attempt to locate the so-called "water war" within that process of development.

\section{THE "WATER WAR"}

It is important to emphasize that the so-called "water war" was and is being fought in the realm of information, and that there are therefore no neutral sources in government or the press upon which to base a discussion. Much of the conflict revolves around how to correctly interpret the 1944 water treaty, and it is not my intention to reach a conclusion in this matter. Rather than seek to determine who is right and who is wrong, this article analyzes the changing positions taken by the various actors and the evolving dynamics between them, and locates these positions and dynamics in a longer ecological and economic history of the borderlands. Although it makes no effort to resolve the conflict, this article does suggest that this and other international conflicts over water will be more quickly and more justly resolved when those local and regional stakeholders directly involved in the use and management of the resource take on - and are allowed - a greater role in their resolution. Finally, while this article focuses on the delta region of the Rio Bravo/ Grande, it is not my intention to defend or promote the political positions or projects generated by the actors of that particular region, but rather to argue that regional political processes in general should be considered a key element of sustainability.

Farmers on the Texas side of the Lower Rio Bravo Valley began to notice diminishing water supplies in 1993. ${ }^{17}$ By 1995 the Irrigation District \#25, surrounding the town of Matamoros, Tamaulipas in the lower Rio Bravo Valley, was only receiveing 50\% of the customary amount of water. ${ }^{18}$ For the 5-year period between 1992 and 1997, Mexico was unable to deliver the amount of water stipulated by the Treaty of 1944, and ended this cycle - cycle 25 - owing 1,263 million cubic meters to the United States. ${ }^{19}$ By this point there was no doubt that the demand for water exceeded the availability of water in the river basin. There were, however, many doubts concerning the reasons for the shortfall, and these doubts led shortly to conflicts among the different regions of the river basin and their water users.

The most immediate and seemingly obvious reason given for the shortfalls in water was drought. But those who had their water supplies cut - principally the farmers on both sides of the Lower Rio Grande Valley - were not content with that answer, and began to suspect that they the regions higher up on the river were taking more than their share of the water, and less of their share of the risks and damages. When they sought information concerning rainfall, stream flow, and reservoir levels, they found that it was not readily available. The lack of information only aggravated their suspicions of poor management of the water resources in the river basin. How are we to know that the farmers on the Mexican tributaries of the Rio Bravo aren't using the water instead of sending it to us?, farmers in Texas asked. And is the shortfall in water availability due more to drought, or to overuse by the upper river users? Rumors and other sources of information confirmed their suspicions: during 1996 and 1997, news spread that farmers in the state of Chihuahua continued irrigating their crops even when Mexico failed to deliver water to users in south Texas, as stipulated by the 1944 Treaty. ${ }^{20}$ In 1999, when Mexico still had not fulfilled its water obligations from the $1992-1997$ period, a research firm in Texas reported that there were 6 million acre-feet of water stored in Chihuahua. ${ }^{21}$ This claim had serious implications: was Mexico not honoring the Treaty?

By the mid-1990s, in this context of water shortages, suspicion and informational opacity, it

17. Diario de Juárez (3-19-02).

18. La Jornada (10-1-01).

19. La Jornada ID (septiembre, 2001).

20. La Jornada (5-4-02).

21. Fort Worth Star Telegram (3-20-01). 
became clear that there were serious political problems in the management of the binational river system. According to the Treaty, each government is responsible for providing data about stream flow and water resources in their own territory. These two sides meet in the International Boundary and Water Commission to make water management decisions based on that information. Although the decisions about water in the borderlands have clear political and economic ramifications, this Commission has generally operated with a great deal of autonomy from any democratic political process. To a large degree this is because most of the decisions taken by the IBWC are quite technical, and are considered to be the domain of engineers rather than politicians, not to mention everyday water users. But the lack of democratic process makes it exceptionally easy for federal governments to control the management of the binational water. Without transparent decision making based on reliable published information, the users on both sides of the river system had serious doubts that the water was being managed equitably on their behalf.

The interrogation of the management of the river system was led by those most hurt by the water shortfall: the farmers on both sides of the Lower Rio Bravo Valley. It was - and is - a process of political struggle in which claims for water were couched by these farmers and their representatives in a variety of political languages including, most importantly, discourses of rights and region. It was also an educational process, in which local actors learned about water management and the 1944 Treaty in order to make claims for water. And, in this educational process, a consciousness was articulated of the common economic and ecological position shared by the two sides of the river. This consciousness, articulated in the context of the crisis of irrigated agriculture, is remarkably similar to that expressed by Chávez and Robertson some 60 years earlier, when the irrigated agricultural development model was just being consolidated.

The conflict that had been brewing since 1992 came to a head in 2000 and 2001, which were the 9th and 10th driest years on record in the Lower Rio Grande Valley. ${ }^{22}$ According to representatives of the agricultural sector in northern Tamaulipas, Mexico's National Water Commission (the CNA) stopped all delivery of water to Irrigation District 25 in March 2000. In September the CNA informed the farmers that water levels in the international dams were low, but did not explain to them why. Using hydrological information published on the web page of the US section of the IBWC, the farmers learned that it was because water had delivered to the United States, in order to pay that year's water quota as well as some from previous years. ${ }^{23}$ The farmers of northern Tamaulipas were incensed: why was a scarce national resource being sent to Texas, when Mexican farmers were suffering just as much? Things were not any quieter in Texas, where, despite the water deliveries, farmers and ranchers were threatening to sue Mexico in International Court for two thousand million dollars in damages caused by what they argued was Mexico's failure to comply with the 1944 Treaty. ${ }^{24}$

But just when the battle line seemed to be forming at the international border, the leaders of the farmers on the Mexican side of the Valley launched their own broadside against the Mexican federal government for failing to comply with its own laws, including the Treaty of 1944. Alvaro Rivera, spokesman for the farmers of northern Tamaulipas, published an open letter to recently elected President Vicente Fox, listing the illegalities permitted or perpetrated by Mexico's National Water Commission (the Comision Nacional de Agua, or CNA) and demanding that the President enforce the laws governing the use of water in the river system. Northern Tamaulipas, Rivera argued, was victim of an illegal overuse of water in the upper reaches of the river system. To add insult to injury, the water transfers made to placate the Texas farmers were not taken from all the Mexican states, but only from Tamaulipas, a measure he considered to be against the letter of the 1944 Treaty. Rivera demanded that a 1955 moratorium on the use of water throughout the river basin be respected, and that illegal uses of water be eliminated. He also demanded that the CNA create an official and transparent information system to monitor the uses and volumes of water in the river basin. President Fox, of the National Action Party (PAN), is the first president in 70 years to break the monopoly of power held by the Institutional Revolutionary Party (PRI). Underlying the demands of the Mexican farmers was a call to Fox to live up to his campaign

22. The McAllen Monitor (2-1-02).

23. La Jornada (9-24-01).

24. Cambio (8-5-01). 


\section{Casey Walsh}

promise of "change" and clean up the corruption and disorder that reigned in the river basin.

Despite the growing militancy of the Tamaulipas farmers against their national government, the pressure of the Texans was stronger and better placed. The farmers and ranchers of South Texas went to their congressmen and their Republican governor, Rick Perry, who gained the support of President Bush, himself a former Republican Texas governor. Bush and Fox, both recently elected, had made US-Mexico relations a priority of their governments. So, in a meeting between the two Presidents in Guanajuato Mexico on February 16th, 2001, Fox promised Bush he would deliver more water from the Mexican tributaries to the farmers of South Texas. ${ }^{25}$ Fox then turned to the CNA, the CILA, and the Secretary of Foreign Relations (SRE), asking that they enable the transfer of water. On March 16 the IBWC/CILA published Minute 307, an operational decree attached to the 1944 Treaty, establishing a schedule to transfer determined quantities of water to US possession in the international dams on the Lower Rio Bravo. But when the CNA went to open the floodgates of the Luis Leon dam on Chihuahua's Rio Conchos, the state governor of Chihuahua sent his police to stop the water transfer. In the state of Coahuila, only about one third of the water promised by the executive branch of the Federal government was actually released from the Don Martin dam. ${ }^{26}$

The resistance to the water politics of the Mexican federal government's executive branch was based in a variety of elements including a nationalist defense of water as Mexican patrimony, a regionalist assertion of the rights of states and regions to control resources and a reaction of regional PRI forces against the national PAN government. At the same time, then, that Fox was working through the institutions of the executive branch, controlled by the PAN, to satisfy the demands of US farmers, Mexican farmers from Tamaulipas were appealing to their governors, congressmen and senators from the PRI. Mexico's Senate demanded a voice in the decision making process of the IBWC, and accused Fox and his cabinet members of unconstitutionally disregarding the terms of the 1944 Treaty by writing and signing the Minute 307 that authorized the transfer of water to the US.

By mid-2001 farmers and their representatives on both sides of the Rio Bravo/Grande delta had discovered their common ground in their water struggle; a common regional ecological, economic and political position forged in the process of irrigated agricultural development over the previous century. Chihuahua, they all argued, was the culprit, for having expanded its irrigation zones during the 1960s and 1970s as part of the same general process of borderlands agricultural development that created the Lower Rio Bravo Valley decades before. Tamaulipan farmers repeatedly cited a National Hidraulic Plan from the mid-1950s that declared the uses and availability of water in the river basin to be in equilibrium, and a legal moratorium on further water concessions published at the same time. ${ }^{27}$ In Chihuahua, they argued, entire new irrigation districts were created since then, in utter disregard for the law. Now the upper basin was using all the water, leaving the binational lower basin dry. This common ground was reinforced by a series of cross-border meetings at the end of 2001 and the beginning of 2002 between farmers from both sides of the Lower Rio Bravo/Grande Valley. Álvaro Rivera gave a presentation at a meeting at the Texas A\&M Agricultural Extension facility, arguing that Chihuahua was hoarding water. Using data provided by the IBWC, he told the audience that rainfall in the upper drainage was only about $10 \%$ less than the average, but that $76 \%$ less water was arriving to the international dams. ${ }^{28}$ A few days later, a group of Texas farmers met with Tamaulipans in Matamoros, where they were informed that the water they received from the Mexican government was taken illegally from the farmers of northern Tamaulipas. A representative of the Texas farmers declared that "we have a Mexican ally on our side now... Tamaulipas is going to help us by joining hands with us in pressuring the federal government to do something." And in February of 2002, when Texas farmers began to speak of a boycott against Mexican agricultural products and the retention of water from the Colorado River, the Tamaulipan farmers declared their solidarity.

But while both sides wanted water, and recognized their common position in relation to the

25. El Norte (3-20-01); El Bravo de Matamoros (4-4-01); The McAllen Monitor (7-31-01); La Jornada ID (September 2001).

26. El Bravo de Matamoros (3-19-01).

27. El Bravo de Matamoros (1-1-02).

28. McAllen Monitor (12-4-01). 
upper river basin, the Texans and the Tamaulipans differed on many counts. Where the Texans found an ally in Fox and the Executive branch of the Mexican Federal government, the Tamaulipans found an enemy. The Texans backed their demand for water with an appeal to the letter of the 1944 Treaty, but were entirely unconcerned with the legality of the water transfer decreed by Minute 307. The Tamaulipans were equally focused on securing water, and also based their demands in the 1944 Treaty. But they sought every means possible to detain the water payment to the Texan farmers and to reassert the rule of law in the river basin. These measures included legal suits that detained the enactment of Minute 307 and the transfer of water to Texas, as well as Senate points of accord demanding monetary compensation for the Tamaulipas farmers, and compliance with the laws governing the river basin. ${ }^{29}$ The Tamaulipans argued that because the Federal government was unable to get water from the upper basin due to political resistance from state governments, it took water promised to Tamaulipas by the 1944 Treaty to pay the farmers in Texas. They maintained that this was unconstitutional and was therefore a theft of national waters, and they openly accused the Fox government of treason. "We are offering help to the US with Chihuahua," Álvaro Rivera said, "but this water should belong to us"..$^{31}$

The complex regional struggles to control the water of the Rio Bravo had serious implications at the national and international levels. Because of regional resistance, Fox's government was unable to fulfill its promise to Bush that Mexico would deliver water. As a result, foreign relations minister Alberto Szekeley was forced to abruptly change the government's position concerning its water debt, declaring at the end of 2001 that Mexico was in a situation of "extreme drought", and, according to the 1944 Treaty, did not have to comply with the water payments agreed upon in Minute 307. This declaration opened rifts between the two sides of the IBWC/CILA. A few weeks before Szekeley's statement Sally Spencer, IBWC spokesman, told the press that there was enough water in Mexican reservoirs to make a payment. ${ }^{32}$ And shortly after Szekeley's statement IBWC commissioner Carlos Ramirez directly contradicted the Mexican Foreign Relations minister, telling Texas Valley representatives that "there is sufficient enough water for release ... . they have enough to meet our needs and theirs". ${ }^{33}$ Frictions continued between the two sides of the IBWC/CILA, and in February of 2002 US members accused their Mexican counterparts of stalling, by canceling meetings and ignoring US proposals for water payments. $^{34}$ Shortly thereafter George Bush sent a diplomatic note to the Mexican government asking that it establish order in the Rio Bravo river basin. ${ }^{35}$ In mid-February the Mexican courts rejected the various legal suits brought against the government by the Tamaulipan farmers, and, "severe drought" not withstanding, small amounts of water began to flow from the international dams to the Texas Valley. ${ }^{36}$

By spring of 2002 the international dimensions of this conflict over the water of the Rio Bravo/Grande had grown in importance and captured the attention of national presses and publics. When Texas Agricultural Commissioner Susan Combs presented satellite images that she said showed a recent expansion of irrigation in Chihuahua, that state's governor denied such irrigation, and accused Texas of spying on a foreign nation. ${ }^{37}$ The Mexican Embassy maintained that Bush and Fox would not discuss the water issue in the United Nations Development summit in Monterrey in April, while the US government maintained that a discussion was indeed scheduled. $^{38}$ Texas Governor Rick Perry jumped into the fray, threatening economic boycotts, and by April US ambassador to Mexico Jeffrey Davidow publicly suggested that Mexico had failed to

29. La Jornada (9-24-01).

30. La Jornada (9-24-01); El Bravo de Matamoros (3-5-02); El Bravo de Matamoros (3-6-02).

31. McAllen Monitor (12-8-01).

32. Diario de Juarez (10-4-01).

33. McAllen Monitor (10-23-01).

34. McAllen Monitor (2-1-02).

35. El Bravo de Matamoros (2-18-02).

36. El Bravo de Matamoros (2-20-02).

37. McAllen Monitor (3-14-02).

38. McAllen Monitor (3-14-02). 


\section{Casey Walsh}

comply with the 1944 Treaty. ${ }^{39}$

In response to the aggressive tone of the "water war", voices from both sides of the border spoke up in favor of diplomatic process, negotiated reforms and other constructive measures. Mary Kelly, then at the Texas Center for Policy Studies, proclaimed that there was no water in Mexico to be had, and that Texas farmers were irrational in their demands. She suggested that both countries deescalate the tensions and called for a binational summit to create a plan for the sustainable administration of the river basin. ${ }^{40}$ Chihuahua senator Jeffrey Jones echoed her sentiments, suggesting the creation in Mexico of a border council at the level of the national congress, that could then contribute to a binational process of integrated river basin management. ${ }^{41}$ In June 2002 CNA director Cristobal Jaime Jaques unveiled a "Plan for the Sustainable Use of Surface Water of the Rio Bravo", which acknowledged that the government had conceded too many water concessions, and proposed a series of measures to establish order and regain equilibrium in the Mexican side of the river basin. ${ }^{42}$ The centerpiece of this plan was a 1,535 million peso budget funded by the North American development Bank and the Canadian International Development Agency for more efficient irrigation technology. ${ }^{43}$ American Ambassador Davidow accepted that Mexico did not have water, and suggested collaborative medium- and long-term solutions to the water crisis. And, at the Border Governor's conference in June, even Texas governor Rick Perry and Chihuahua governor Patricio Martínez made gestures of support for a process of water management between the two federal governments.

The water crisis is far from being resolved. The improvement of hydraulic infrastructure is underway, as is work on a document to regulate the use of water in the river basin. ${ }^{44}$ Both of these measures are mandated by Minute 308 of the 1944 water Treaty, published in June 2002 by the IBWC/CILA. ${ }^{45}$ The farmers of northern Tamaulipas continue to struggle for the democratization of the management of the river basin, challenging the federal government's reforms at every step, seeking and receiving monetary compensation for the water denied to them. In early 2003 such a monetary compensation was given by the Mexican government to the farmers of northern Tamaulipas. However, some of the demands of the farmers of Tamaulipas are not likely to be included in any river basin management plan, or, if they are, they are not likely to be carried out. For example, the Tamaulipans want all water users who gained concessions after 1955 to be stricken from the list and denied water. This is almost certainly not going to happen, because of the sheer political difficulty of doing so. On the other hand, the federal government has spoken of changes that threaten established agriculture in Tamaulipas. Most drastic among these would be a reduction of the size of the irrigation districts in the Lower Rio Bravo Valley, and a shift from the production of basic grains to the production of more profitable crops for export.

\section{CONCLUSIONS}

The crisis of water, manifested in the so-called "water war," is a crisis of irrigated agricultural development. What will most likely emerge from this present conjuncture is a technological response that enables this development to maintain its present importance or even to expand. Although there is an awareness on the part of many in the borderlands, including elements of both federal governments, that a truly sustainable form of development in the desert must move away from irrigated agriculture, such a move is politically unfeasible. Continued massive subsidies for US agriculture, however, combined with continued de facto trade barriers protecting US markets from Mexican imports may indeed force some irrigation zones in northern Mexico to make dramatic acreage reductions or simply stop cultivation. Because they produce low-profit grains, are the last in the river basin to receive water, and are dependent on antiquated

39. Universal (4-15-02); Reforma (4-16-02); McAllen Monitor (4-24-02).

40. La Jornada (5-4-02).

41. El Bravo (5-28-02).

42. Universal (6-5-02); Diario de Juárez (6-4-02) .

43. El Bravo de Matamoros (5-31-02); La Jornada (6-20-02).

44. El Mañana de Nuevo Laredo (8-13-02).

45. This document can be found on the IBWC web page. 
infrastructure and techniques of flood irrigation, the irrigation zones of the Mexican side of the Lower Rio Bravo/Grande seem to be particuarly exposed to that threat. The hope of many is that anonymous and seemingly apolitical market forces can be brought to bear on the management of water in the region, greatly increasing the price of the resource. A higher cost of water, the reasoning goes, will make the current mode of irrigated agricultural production unprofitable, prompting the creation of new hydraulic infrastructure and a displacement of the present crisis into the future. Such investment, should it occur, will most likely bring with it a switch to crops that are both labor- and capital-intensive, the concentration of land and other capital in the hands of relatively few large businessmen, contract farming, the growth of migrant labor circuits to the region, and other phenomena characteristic of commercial agriculture in places like Chile, Baja California, and California (J.V. Palerm 1984; H C. de Grammont 1999 et. al.).

Regardless of how this crisis is resolved, the conflict born of the crisis follows well-worn paths of political mobilization in the borderlands. As was the case in the region in the late 1930s, and as has happened in other agricultural regions on the border (Ward 2003), actors on both sides of the river have pressured their federal governments to resolve regional problems, sharpening national-level conflicts in the process. At the same time, these actors have forged cross-border alliances and projects based in a the recognition of a shared regional ecology and economy. The conflict also hints at the emergence of new political processes and structures. One of the most interesting dimensions of the ongoing "water war" is the creation of legal and managerial capacity among some of the water users. We have seen that the struggle of farmers in the Lower Rio Bravo Valley has involved an education in water law and in river basin management. It has raised some consciousness about the nature of water as a scarce resource in the borderlands, and has provided a harsh lesson in the social and economic value of the resource. The efforts of the farmers of northern Tamaulipas to secure water for their crops has led them to make us of their political representatives and, more surprising, Mexico's legal system. They have relentlessly pursued the establishment of a functioning river basin council, or "consejo de cuenca", composed of representatives of the various sectors from the different regions of the river basin. This has been a struggle to decentralize and democratize state power that will, perhaps, have a lasting impact on water politics and society in the borderlands. The recently approved reforms to Mexico's national water law, which award increased capacity to the consejos de cuenca, may signal such an impact. ${ }^{46}$

The challenge now facing those interested in the sustainable management of water in the borderlands is to build upon such regional struggles and projects while escaping their narrow confines. Less powerful and less organized social actors, in all regions of the river basin, must be assured a significant presence in the legal and political process of water management. The struggles of the irrigated agricultural sector in the Rio Bravo/Grande have, at times, managed to transcend the national border. In their mobilization to secure water, farmers from both sides of the Lower Rio Bravo Valley have come to understand the common ground they share, and the fragility of the livelihoods of all those that live within the precarious ecological conditions of the borderlands. This understanding must be achieved on grander scales throughout the river basin, as a basis for effective transregional and transnational "governance" of water. Despite the challenges, these regional histories and others suggest the possibility of a cooperative, democratic binational management of the water resources of the Rio Bravo/Grande.

\section{References Cited}

Aboites, Luis.

1987. La irrigación revolucionaria: Historia del Sistema Nacional de Riego del Río Conchos, Chihuahua. 1927-1938. México: SEP/CIESAS.

46. Comisión de Asuntos Legislativas, Mexican Senate. (April 23, 2003). "Dictamen de las Comisiones Unidas de Recursos Hidráulicos y de Estudios Legislativos, Segunda, a las iniciativas que reforman, adicionan y derogan diversas disposiciones de la Ley de Aguas Nacionales." Manuscript. 
Casey Walsh

Anguiano Tellez, Maria Eugenia.

1995. Agricultura y migración en el valle de Mexicali. Tijuana: COLEF.

Balderrama, Francisco and Raymond Rodríguez.

1995. Decade of Betrayal: Mexican Repatriation in the 1930s. Albuquerque: University of New Mexico Press.

Bennett, Vivienne.

1996. The Politics of Water: Urban Protest, Gender, and Power in Monterrey, Mexico. Pittsburgh: University of Pittsburgh Press.

Bernal, Victoria.

1991. Cultivating Workers: Peasants and Capitalism in a Sudanese Village. New York: Columbia University Press.

Carmona, Fernando, et. al.

1996. El Milagro Mexicano. México: Editorial Nuestro Tiempo.

Comisión Nacional de Irrigación.

1928. El desarrollo de la irrigación en México. Publicaciones de la Comision Nacional de Irrigación, Numero 10. México: CNI.

1930. Estudio agrícola y económico, Sistema de Riego "Rio Salado." México: Editorial Cultura.

Coronado, Irasema

1999. "Water Conflict in the Borderlands." Borderlines7(6) (www.us-mex.org/borderlines).

DeWalt, Billie.

1985. "Mexico's Second Green Revolution: Food for Feed" Mexican Studies / Estudios Mexicanos 1(1): 29-60.

Enríquez Coyro, Ernesto.

1976. El Tratado entre México y los Estados Unidos de América sobre Ríos Internacionales: una lucha nacional de noventa años. México: UNAM.

Gamio, Manuel.

1931. "Migration and Planning" Survey Graphic 66.

1987(1935). Hacia un México nuevo: problemas sociales. México: Instituto Nacional Indigenista.

C. de Grammont, Hubert. et. al. coordinadores.

1999. Agricultura de exportación en tiempos de globalización: El caso de las hortalizas, frutas y flores. México: Universidad Autonoma Chapingo.

Greenberg, James.

1998. "The Tragedy of Commoditization: Political Ecology of the Colorado River Delta's Destruction." Research in Economic Anthropology 19: 133-149.

Hewitt de Alcantara, Cynthia.

1976. Modernizing Mexican Agriculture. Geneva: United Nations Research Institute for Social Development.

Heyman, Josiah McC.

1994. "The Mexico-United States Border in Anthropology: A Critique and Reformulation." Journal of Political Economy 1(1): 43-65.

Hundley Jr, Norris.

1966. Dividing the Waters: A Century of Controversy Between the United States and Mexico. Berkeley and Los Angeles: University of California Press.

Isaacman, Allen.

1996. Cotton is the Mother of Poverty. Portsmouth, Cape Town and London: Heinemann, David Philip, and James Currey

Kelly, Mary, Artuso Solís and George Kourous.

2001. "The Border's Troubled Waters: Parts I and II." Borderlines 9(10) (www.us-mex.org/ borderlines).

Kerig, Dorothy P.

2001. El valle de Mexicali y la Colorado River Land Company, 1902-1946. Mexicali: UABC. Martínez Saldaña, Tomás.

1999. La diaspora tlaxcalteca. Tlaxcala: Gobierno del Estado de Tlaxcala.

McWilliams, Carey.

1942. Ill Fares the Land: Migrants and Migratory Labor in the United States. Boston: Little, Brown and Company. 
Meyers, William K.

1994. Forge of Progress, Crucible of Revolt: the Origins of the Mexican Revolution in La Comarca Lagunera, 1880-1910. Albuquerque: University of New Mexico Press.

1998. "Seasons of Rebellion: Nature, Organization of Cotton Production and the Dynamics of Revolution in La Laguna, Mexico, 1910-1916" Journal of Latin American Studies 30: 63-94.

Montejano, David.

1987. Anglos and Mexicans in the Making of Texas, 1836 - 1986. Austin: University of Texas Press.

Palerm, Juan-Vicente.

1994. "La intersección del agua y el trabajo en la moderna agricultura de California" Sistemas hidráulicos, modernización de la agricultura y migración. Carmen Viqueira Landa and Lydia Torre Medina, coordinators. México: Universidad Iberoamericana / El Colegio Mexiquense.

Peach, James and James Williams.

2000. "Population and Economic Dynamics on the U.S.-Mexican Border: Past, Present, and Future" The U.S.-Mexican Border Environment: A Road Map to a Sustainable 2020. Ganster, Paul, ed. San Diego: San Diego State University Press.

Peloso, Vincent C.

1999. Peasants on Plantations: Subaltern Strategies of Labor and Resístanse in the Pisco Valley, Peru. Durham and London: Duke University Press.

Plana, Manuel.

1991. El reino del algodón en México. La estructura agraria de la Laguna. Torreón: Ayuntamiento de Torreón, et. al.

Porter, Philip W.

1995. "Note on Cotton and Climate: A Colonial Conundrum." Cotton, Colonialism and Social History in Sub-saharan Africa. eds. Allen Isaacman and Richard Roberts. Portsmouth, Capetown and London: Heinemman, David Philip and James Currey.

Reisner, Marc.

1993. Cadillac Desert: The American West and its Disappearing Water. New York: Penguin.

Roberts, Richard L.

1996. Two Worlds of Cotton: Colonialism and the Regional Economy in the French Soudan, 1800-1946. Stanford: Stanford University Press.

Walsh, Casey.

2001. Development in the Borderlands: Cotton Capitalism, State Formation and Regional Political Cutlure in Northern Mexico. PhD Dissertation, New School for Social Research.

2004. "Eugenic Acculturation: Manuel Gamio, Migration Studies, and the Anthropology of Ward, Evan. Development in mexico, 1910-1940." Latin American Perspectives 31(5):118-145.

2003. Border Oasis: Water and the Political Ecology of the Colorado River Delta, 1940-1975. Tucson: University of Arizona Press.

Warman, Arturo.

2001. El campo mexicano en el siglo veinte. México: Fondo de Cultura Economica.

Weber, Devra.

1994. Dark Sweat, White Gold: California Farm Workers, Cotton, and the New Deal. Berkeley: University of California Press.

Worster, Donald.

1985. Rivers of Empire: Water, Aridity and the Growth of the American West. New York: Pantheon Books. 


\title{
Casey Walsh
}

\begin{abstract}
Since 1992 water scarcity in the Río Bravo/Rio Grande river basin has heightened tensions and conflicts among water users and politicians on both sides of the Mexico-U.S. border. This article argues that while this situation has been characterized as an international "water war" stemming from a "water crisis," it is more accurately described as a series of conflicts between regional, binational and national actors generated by a "crisis of irrigated agriculture." A close examination of the dynamics of these current water conflicts focused on the delta region of the Rio Bravo/Grande reveals a binational ecological consciousness among the agricultural users of the resource, the product of a long history of irrigated agricultural development in the borderlands. The article argues that these conflicts must be understood historically, and suggests that these binational, regional dynamics should be cultivated in the effort to negotiate the social dimensions of the crisis of irrigated agriculture in the borderlands, and to establish a more sustainable and democratic process of water management in the river basin.
\end{abstract}

Key Words: Irrigation; Agriculture; Conflict; Borderlands; Water.

\section{Resumé}

Depuis 1992 la manque de l'eau dans le bassin fluvial du Río Bravo/Rio Grande a augmenté les conflits et la tension parmi les usagers de l'eau et les politiciens sur les deux côtés de la frontière entre le Mexique et les Etats-Unis. Cet article propose que ce qui a été présenté comme une guerre internationale sur l'eau qui tire sa justification d'une crise de l'eau serait mieux caractérisée comme une série de conflits régionaux et binationales où les acteurs du drame sont motivés plutôt par une crise de l'agriculture irriguée. Un regard de près sur la dynamique des conflits actuels dans le delta du Río Bravo/Rio Grande révèle une conscience écologique parmi les usagers agricoles qui est le produit d'une longue histoire d'aménagement irrigué dans la frontière. L'article propose que ces conflits doivent être examinés dans leur contexte historique, et il suggère que ces dynamiques régionales et binationales doivent être cultivées dans le but de négocier une dimension sociale de la crise d'agriculture irriguée dans la frontière et à fin d'établir un processus plus démocratique et plus soutenable pour l'aménagement de bassin du fleuve.

Mots clefs : l'irrigation, l'agriculture, le conflit, la frontière, l'eau.

\section{Resumen}

Puesto que la escasez de aguas en 1992 la cuenca del río de Río Bravo/Rio Grande ha aumentado las tensiones y conflictos entre los usuarios del agua y los politicos en ambos lados de la frontera de Mexico-U.S.. Este artículo discute que mientras que se ha caracterizado esta situación como una "guerra internacional del agua" que proviene de una "crisis del agua," él se describe más exactamente como serie de conflictos entre actores regionales, binationales y nacionales generada por una "crisis de la agricultura irrigada." Una examinación cercana de la dinámica de estos conflictos actuales del agua se centró en la región del delta de la Río Bravo/ Grande revela un sentido ecológico del binational entre los usuarios agrícolas del recurso, el producto de una historia larga del desarrollo agrícola irrigado en la zona fronteriza. El artículo discute que estos conflictos se deban entender históricamente, y sugiere que este binational y regional dinámica sea cultivado en el esfuerzo de negociar las dimensiones sociales de la crisis de la agricultura irrigada en la zona fronteriza, y establecer un proceso más sostenible y más democrático de la gerencia del agua en la cuenca del río.

Palabras claves: Irrigación; Agricultura; Conflicto; zona fronteriza; Agua. 